Tarbawy : Jurnal Pendidikan Islam

ISSN : 2407-4462 (Cetak), 2614-5812 (Elektronik)

Vol. 5, No. 1, 201x, Hal. 1 - 10

DOI: https://doi.org/10.32923/tarbawy.v5i1.824

\title{
On/Off-The Job Training Guru : Sebuah Keniscayaan dalam mendukung Peningkatan Efektivitas Pembelajaran
}

\author{
Andi Arif Rifa'i ${ }^{1}$, \\ ${ }^{1}$ IAIN Syaikh Abdurrahman Siddik Bangka Belitung
}

\begin{tabular}{lll}
\hline \hline Info Artikel : & ABSTRAK (9PT) \\
\cline { 3 - 3 } Diterima & : 01 Maret 2018 & \\
Direvisi & : 23 Maret 2018 & manusia yang unggul dan berdayasaing global. Produk pendidikan tersebut \\
Dipublish & dapat terwujud secara nyata dan berkualitas hanya jika didukung oleh guru- \\
& & guru yang sadar akan profesinya ('melek profesi'). Pemerintah sebagai \\
& pelindung masyarakat juga harus secara maksimal mengambil peran dalam \\
& mendukung upaya-upaya pengembangan professional guru. Dengan guru- \\
& guru yang dinamis berkembang mengkuti perkembangan IPTEK kualitas \\
& sumber daya manusia secara linier juga berkembang menuju titik puncak \\
& tujuan pendidikan nasional. Alokasi anggaran pendidikan yang mendukung \\
& peningkatan kualitas guru harus menjadi titik sentral selain daya dukung \\
& pendidikan lainnya. Peberian training (on atau off) kepada guru harus \\
& diprogram secara tepat sasaran dan berkelanjutan. Sehingga guru-guru sebagai \\
& sosok terdekat dengan siswa mampu menghadirkan pembelajaran efektif ke \\
& dalam kelas dan mendukung mutu pendidikan.
\end{tabular}

\section{Kata Kunci:}

Training Guru

Efektifitas Pembelajaran

Mutu Pendidikan

Keyword :

Teacher Training

Learning Effectiveness

Quality of Education

\begin{abstract}
Education is one of the 'machines' that produce superior and globalized human resources. The educational product can be realized in a tangible and qualified way only if supported by teachers who are aware of their profession ('literate profession'). The government as a protector of society must also maximally take a role in supporting the efforts in professional development of teachers. With growing dynamic teachers following the development of science and technology, the quality of human resources is also linearly evolving toward the top point of national education goals.

The allocation of education budgets that support teachers quality improvement should be a central point in addition to other educational support capacities. Teacher training (on or off) should be programmed in an appropriate and sustainable target. So that teachers as the closest to the students are able to present effective learning into the classroom and support the quality of education
\end{abstract}

This is an open access article distributed under the Creative Commons Attribution License, which permits unrestricted use, distribution, and reproduction in any medium, provided the original work is properly cited. (C2019 by author.

\section{Koresponden: \\ Andi Arif Rifa'i, \\ Email: andiarifrifai@gmail.com}

\section{Pendahuluan}

Pendidikan merupakan sebuah wasilah dalam menghantarkan manusia pada pencapaian kedewasaan secara kognitif, afektif dan psikomotor. Tidak hanya berhanti pada titik tersebut, perkembangan zaman telah membawa tuntutan baru pada dunia pendidikan yaitu menghasilkan sumber daya manusia (SDM) yang mampu bersaing pada era globalisasi. Persaingan nyata dalam bingkai globalisasi dunia, menjadikan setiap negara harus mengambil peran penting dalam menjaga kualitas pendidikannya. Sebab, hanya dengan pendidikan yang berkualitas anak-anak bangsa dapat berkompetisi pada level yang lebih tinggi (dunia).

Era globalisasi juga telah mengubah trend pendidikan dengan menggeser orientasi suatu bangsa, sehingga menempatkan pembangunan manusia seutuhnya hanya dapat dilakukan melalui pendidikan dan latihan dalam berbagai jenis, jenjang, sifat dan bentuknya. Dalam konteks Indonesia, pendidikan manusia seutuhnya diidealisasikan menjadi titik puncak tercapainya tujuan pendidikan nasional. Sosok pribadi yang diidolakan (manusia seutuhnya) tersebut belum juga dihasilkan (diwujudkan), oleh karenanya lembaga pendidikan dijadikan espektasi alternatif, sebagai instrumen utama proses kemanusiaan dan pemanusiaan manusia, dengan menghargai dan memberi kebebasan untuk berpendapat dan berekspresi (Djuwarijah, 2008). Belum terwujudnya tujuan pendidikan nasional memberikan sinyal kuat pada pemerintah untuk melakukan perbaikan secara mendasar dalam penyelenggaraan sistem pendidikan nasional yang ada.

Kewajiban pemerintah dalam penyelenggaraan pendidikan sejalan dengan Pembukaan UUD (Undangundang Dasar) dan batang tubuh konstitusi (Pasal 20, Pasal 21, Pasal 28 C ayat (1), Pasal 31, dan Pasal 32) yangmana 
mengamanatkan bahwa pemerintah diharuskan mengusahakan dan menyelenggarakan satu sistem pendidikan nasional dan memajukan kebudayaan nasional untuk meningkatkan keimanan dan ketakwaan kepada Tuhan Yang Maha Esa serta akhlak mulia dalam rangka mencerdaskan kehidupan bangsa (Kemendikbud, 2014). Artinya pemerintah memiliki beban tugas konstitusi yaitu menyelenggarakan pendidikan yang adil dan merata bagi seluruh warga negara Indonesia, dengan mengedepankan mutu dan daya dukung pendidikan guna menghasilkan SDM yang berdaya saing tinggi.

Pendidikan pada prisipnya merupakan hak asasi setiap warga negara Indonesia dan oleh karenanya setiap warga negara berhak memperoleh pendidikan yang bermutu sesuai dengan minat dan bakat yang dimilikinya tanpa memandang status sosial, status ekonomi, suku, etnis, agama, dan gender. Pemerataan akses dan peningkatan mutu pendidikan berpeluang membuat warga negara Indonesia memiliki kecakapan hidup (life skills) sehingga mendorong tegaknya pembangunan manusia seutuhnya serta masyarakat madani dan modern yang dijiwai nilai-nilai Pancasila, sebagaimana yang telah diamanatkan dalam UU No 20 Tahun 2003 tentang Sistem Pendidikan Nasional (Kemendikbud, 2014).

Pemerataan dan peningkatan mutu pendidikan mustahil terwujud tanpa didukung dengan alokasi anggaran yang memadai. Besaran anggaran pendidikan sejak tahun anggaran 2009 telah merepresentasikan amanat UUD 1945 dan UU Sisdiknas (sesuai dengan keputusan Mahkamah Konstitusi No. 13 Tahun 2008) dengan dialokasikannya anggaran pendidikan sebesar $20 \%$ oleh pemerintah dalam APBN. Total anggaran pendidikan pada tahun 2009 mencapai Rp. 207 triliun atau 20\% dari APBN (sebesar Rp. 1.037 triliun), dengan kondisi pertumbuhan ekonomi tahun 2009 sebesar 4\% dan tingkat inflasi 3,5\%. Pada tahun 2010, besaran alokasi anggaran pendidikan 20\% dari APBN adalah sebesar Rp. 225,2 triliun, yang terdiri dari; Rp. 128,7 triliun disalurkan melalui belanja transfer ke daerah dan sebesar Rp. 96,5 triliun disalurkan melalui belanja kementerian/lembaga (Kemendikbud, 2014). Sedangkan pada tahun 2017 alokasi anggaran pendidikan sebesar 416,1 triliun Rupiah, setara dengan 20\% dari total Anggaran Belanja Negara (APBN) sebesar Rp. 2080.5 triliun (Kemenkeu, 2017). Artinya secara kuantitas (angka) besaran anggaran pendidikan telah memenuhi prosentase minimal (20\%) sesuai dengan amanat Undang-Undang.

Besaran anggaran pendidikan tidak cukup berhenti pada kuantitas akan tetapi juga harus berdampak nyata secara kualitas. Artinya, alokasi anggaran tersebut wajib tepat pada sasaran, yaitu guna mendukung peningkatan mutu pendidikan. Mutu pendidikan tidak hanya berada pada pemenuhan sarana prasarana akan tetapi juga perlu memperhatikan guru sebagai creator SDM. Guru sebagai salah satu ujung tombak pendidikan sudah sepatutnya mendapatkan perhatian yang lebih serius terkhusus pada peningkatan kemampuan profesionalnya dalam menghadirkan pembelajaran efektif ke dalam ruang kelas guna menciptakan pendidikan yang bermutu. Programprogram peningkatan mutu guru seharusnya direncanakan dengan lebih serius, tepat sasaran dan mengakomodir kebutuhan peningkatan profesionalitasnya.

Program-program peningkatan mutu guru, seperti pelatihan atau penataran (baik on atau of the job training) perlu secara berkesinambungan dilakukan untuk menjaga kesadaran guru sebagai sosok pendidik profesional. Sebab guru bekerja pada wilayah dinamis yang membutuhkan pengembangan-pengembangan keprofesionalan secara berkelanjutan (continuous professional development) dengan senantiasa menambah pengetahuan baru guna mendukung efektivitas pembelajaran. Untuk itu, seorang guru perlu mendapatkan informasi secara lebih cepat dan akurat melalui berbagai bentuk program-program pelatihan yang mendukung pengembangan profesionalnya.

\section{Pembahasan}

A. Bagian ini terdiri konsep, faktor, dan variabel dari penelitian terdahulu. Kemudian melihat hubungan Hakekat Tugas dan Tanggung Jawab Guru

Secara Etimologis, istilah guru berasal dari bahasa India, yang memiliki arti orang yang mengajarkan tentang kelepasan dari sengsara. Sebagaimana dalam tradisi agama Hindu, guru dikenal sebagai maharesi guru, yakni para pengajar yang bertugas untuk menggembleng para calon biksu di bhinaya panti (tempat pendidikan bagi para biksu) (suparlan, 2008). Dalam dunia pendidikan, guru secara sederhana dimaknai sebagai tenaga pendidik yang memberikan sejumlah ilmu pengetahuan (transfer of knowledge) kepada anak didik di sekolah. Oleh karenanya guru merupakan sosok yang berpengalaman dalam bidang profesinya. Dengan keilmuan yang dimilinya, guru dapat menjadikan anak didik menjadi orang yang cerdas (Hamalik, 2007).

Guru disebut juga sebagai pengajar yang bertugas mengajar peserta didik. Kata mengajar pada hakekatnya memiliki makna usaha guru dalam membimbing, mengarahkan, atau mengorganisir belajar, serta menciptakan kondisi atau mengatur lingkungan sedemikian rupa, sehingga tercapai tujuan pembelajaran yang telah ditetapkan. Sebagai pengajar, guru harus memahami hakekat dan arti mengajar dan mengetahui teori-teori mengajar serta dapat melaksanakannya atau menghadirkannya secara efektif ke dalam ruang kelas. Dengan demikian, tugas atau peran seorang guru dalam pembelajaran adalah menyusun rencana belajar mengajar, memudahkan proses belajar mengajar, dan menilai pembelajaran dan hasil belajar (Muhaimin \& Ali, 2004). Penjabaran daripada tugas-tugas guru tersebut adalah sebagai berikut:

\section{Perencanaan Pembelajaran}

Perencanaan merupakan proses menetapkan tujuan dan menyusun metode, atau dengan kata lain cara mencapai tujuan. Proses perencanaan merupakan proses intelektual (intellectual processes) seseorang dalam menentukan arah (tujuan), sekaligus menentukan keputusan untuk diwujudkan dalam bentuk tindakan atau kegiatan dengan memerhatikan peluang, dan berorientasi pada masa depan (Hamalik, 2007). Dalam membuat 
perencanaan pembelajaran seorang guru perlu mempertimbangkan aspek-aspek kecakapan pada Tabel 1 berikut;

Tabel 1 Aspek-aspek Kecakapan Bloom

\begin{tabular}{|c|c|c|c|}
\hline Aspek & $\begin{array}{c}\text { Pengetahuan } \\
\text { (Cognitive) }\end{array}$ & Sikap (Affective) & $\begin{array}{l}\text { Keterampilan } \\
\text { (Pshycomotor) }\end{array}$ \\
\hline \multirow{6}{*}{ Kecakapan } & $\begin{array}{l}\text { Pengetahuan } \\
\text { (knowledge) }\end{array}$ & $\begin{array}{l}\text { Menerima rangsangan } \\
\text { (receiving) }\end{array}$ & Persepsi \\
\hline & $\begin{array}{l}\text { Pemahaman } \\
\text { (comprehension) }\end{array}$ & $\begin{array}{l}\text { Merespon rangsangan } \\
\text { (responding) }\end{array}$ & Kesiapan \\
\hline & Penerapan (application) & $\begin{array}{l}\text { Mengorganisasi nilai } \\
\text { (organization) }\end{array}$ & $\begin{array}{l}\text { Jawaban terarah } \\
\text { (guided respons) }\end{array}$ \\
\hline & penguraian (analysis) & \multirow{3}{*}{$\begin{array}{l}\text { Menginternalisasikan } \\
\text { (mewujudkan) nilai-nilai } \\
\text { atau pemilikan } \\
\text { (characterization by a value or } \\
\text { value complex) }\end{array}$} & $\begin{array}{l}\text { Mekanisme } \\
\text { (mechanism) }\end{array}$ \\
\hline & Pemaduan (synthesis) & & $\begin{array}{l}\text { Jawaban yang komplek } \\
\text { (complex over respons) }\end{array}$ \\
\hline & Penilaian (evaluation) & & Adaptasi (adaptation) \\
\hline
\end{tabular}

Sumber: diadaptasi dari (Muhaimin \& Ali, 2004)

Selain itu, dalam perencanaan pembelajaran guru juga harus memahami fungsi dari perencanaan pembelajaran itu sendiri. Mansoer (dalam Hamalik, 2009:214) berpendapat bahwa fungsi perencanaan dalam kontek organisasi adalah merumuskan tujuan, menentukan strategi menyeluruh (tentang cara pelaksanaan tugas) untuk mencapai tujuan yang telah ditentukan, serta menetapkan hierarki rencana secara menyeluruh untuk mengintegrasikan kegiatan yang diperlukan guna tercapainya tujuan organisasi. Sedangkan dalam pembelajaran, perencanaan memiliki fungsi antara lain;

a. Memberikan pemahaman yang lebih jelas pada guru tentang tujuan pendidikan dan pengajaran yang dilaksanakan;

b. Membantu guru memperjelas pemikiran tentang sumbangan pengajarannya terhadap pencapaian tujuan pendidikan;

c. Menambah keyakinan guru atas nilai-nilai pengajaran yang diberikan dan prosedur yang digunakan;

d. Membantu guru dalam upaya mengenal berbagai kebutuhan dan minat murid serta mendorong motivasi belajar;

e. Mengurangi kegiatan yang bersifat trial and error dalam mengajar, dengan adanya organisasi kurikuler yang baik, metode yang tepat dan menghemat waktu;

f. Memberi kesempatan bagi para guru untuk memajukan pribadi dan pengembangan profesionalnya;

g. Membantu guru memiliki rasa percaya pada diri sendiri dan jaminan atas diri sendiri;

h. Membantu guru memelihara kegairahan mengajar dan senantiasa memberikan bahan-bahan yang aktual kepada murid. (Hamalik, 2007)

Perencanaan pembelajaran yang dilakukan guru pada dasarnya untuk menciptakan pembelajaran yang efektif. Kemampuan guru dalam membuat perencanaan pembelajaran harus terus ditingkat sesuai dengan tuntutan perkembangan zaman serta perkembangan ilmu pengetahuan.

\section{Implementasi Pembelajaran}

Implementasi pembelajaran merupakan tahapan berupa kegiatan belajar-mengajar setelah perencanaan pembelajaran. Kegiatan belajar mengajar melahirkan interaksi unsur-unsur manusia, yang merupakan sebuah proses dalam rangka mencapai tujuan pengajaran (pembelajaran). Dalam konteks ini, guru dengan sadar berusaha mengatur lingkungan belajar agar bergairah bagi peserta didik. Seperangkat teori dan pengalaman yang dimiliki guru digunakan untuk mempersiapkan program pengajaran dengan baik dan sistematis (Djamarah, Syaiful Bahri, 1998).

Dalam kegiatan belajar mengajar, tidak ada satupun yang tidak menggunakan metode pengajaran. Sebab, metode merupakan alat motivasi intrinsik dalam kegiatan belajar mengajar. Menurut Sardiman A.M. metode merupakan alat dari luar yang dapat membangkitkan belajar seseorang (Djamarah, Syaiful Bahri, 1998). Dengan kompleksitas kegiatan belajar-mengajar, maka hampir tidak mungkin untuk menunjukkan dan menyimpulkan bahwa suatu metode tertentu lebih unggul daripada metode yang lain, dalam upaya mencapai tujuan, oleh semua guru, untuk semua murid, untuk semua mata pelajaran, dalam semua situasi dan kondisi, dan untuk selamanya (Muhaimin \& Ali, 2004).

Penentuan metode pembelajaran (pengajaran) didasarkan atau mutlak berpedoman pada tujuan intruksional. Oleh karenanya, dalam perumusan tujuan, guru perlu merumuskannya dengan jelas dan terukur. Sehingga, mudah bagi guru menentukan metode yang sesuai untuk dipilih guna menunjang pencapaian tujuan yang telah dirumuskan (Djamarah, Syaiful Bahri, 1998). Untuk itu, Ardhana (dalam Muhaimin dkk, 1996:82) berpendapat, bahwa terdapat beberapa metode yang mungkin digunakan guru dalam proses belajar mengajar, diantaranya: metode mengingat, metode ceramah, metode diskusi, metode pararel, metode skolastik, metode 
Jesuit, metode vincentius, metode monitoring, metode herbart, metode pemecahan masalah, metode proyek, metode montesori, dan metode studi kasus (Muhaimin \& Ali, 2004). Metode-metode pembelajaran modern lainnya juga telah banyak dikembangkan oleh para ahli, perlu untuk dipertimbangkan, dipelajari dan diterapkan oleh guru dalam pembelajarannya.

Lebih lanjut, seorang guru dalam kegiatan belajar mengajar menurut Roestyah N.K. harus memiliki strategi agar peserta didik dapat belajar secara efektif dan efisien, mengena pada tujuan yang diharapkan. Salah satu langkah untuk memiliki strategi adalah harus menguasai teknik-teknik penyajian atau biasanya disebut metode mengajar. Metode pembelajaran (mengajar) dapat diklasifikasikan menjadi tiga strategi; (1) strategi pengorganisasian isi pembelajaran, (2) strategi penyampaian isi pembelajaran, dan (3) strategi pengelolaan pembelajaran(Djamarah, Syaiful Bahri, 1998).

Implementasi rencana pembelajaran dalam kegiatan belajar-mengajar hakekatnya adalah untuk meningkatkan efektivitas dalam mencapai tujuan pembelajaran. Oleh karena itu, seorang guru harus memiliki preferensi yang baik terkait metode pembelajaran dari yang tradisional hingga modern (terbaru) dan bahkan perlu melakukan pengembangan metode baru. Kemampuan-kemampuan research and development guru perlu dipupuk dan dikembangkan secara berkelanjutan.

\section{Evaluasi pembelajaran}

Tugas evaluasi pembelajaran secara definisi, merujuk pendapat Mehrens dan Lehmann, yang memiliki makna suatu proses merencanakan, memperoleh, dan menyediakan informasi yang sangat diperlukan untuk membuat alternatif keputusan. Sehingga, evaluasi selalu menyangkut pemeriksaan ketercapaian tujuan yang ditetapkan, yaitu untuk mengetahui sejauh mana hasil dari proses kegiatan dapat mencapai tujuan (Ngalim, 2011). Dalam pembelajaran, evaluasi berfungsi mengukur ketercapaian hasil dari pelaksanaan pembelajaran. Artinya evaluasi mengukur pencapaian tujuan pembelajaran oleh peserta didik. Adapun manfaat yang dapat diberikan dari data evaluasi, antara lain:

a. Manfaat administratif

Kegunaan data hasil evaluasi bagi sekolah adalah untuk melengkapi data terkait tingkah laku murid, minat kecakapan, dan menjadi dasar bagi evaluasi perkembangan individu atau untuk pengelompokan kelas. Selain itu, juga digunakan sebagai laporan kepada orang tua, serta sebagai laporan periodik kepada instansi terkait (lebih tinggi).

b. Manfaat instruksional

Data evaluasi dapat digunakan oleh kepala sekolah dalam melakukan supervisi (pembinaan) guru. Data evaluasi dijadikan dasar dalam usaha membantu atau menolong guru dalam cara mengajar (desain instruksional) yang lebih baik. Apa yang dilakukan guru dalam pembelajarannya dilakukan evaluasi terkait metode-metode mengajar dan bahan-bahan pelajaran yang diberikan, kemudian bagaimana mengubah dan memperbaiki cara-cara mengajar dan hubungan murid sebaik-baiknya.

c. Manfaat untuk Bimbingan dan penyuluhan (bimbingan-konseling)

Guru dan konselor sekolah menggunakan data-data hasil evaluasi yang ada untuk memberikan bimbingan kepada murid terkait pertumbuhan dan perkembangan fisik, mental, emosional dan sosial.

d. Manfaat untuk penyelidikan

Dalam hal penyelidiakan, data dari hasil evaluasi dapat dijadikan bahan penyelidiakan terkait keefektifan mengajar, kurikulum, sistem pengajaran, kesulitan-kesulitan belajar murid, dan lain-lain (Ngalim Purwanto, 2009).

Evaluasi pembelajaran sebagai tahapan lanjut setelah perencanaan dan implementasi pembelajaran, memiliki posisi penting dalam upaya memperbaiki pembelajaran. Hasil evaluasi pembelajaran dapat dijadikan titik awal bagi guru untuk memperbaiki pembelajarannya serta digunakan kepala sekolah dan/atau supervisor (pengawas) untuk membantu guru dalam meningkatkan efektivitas pembelajaran dengan melakukan berbagai perbaikan dari berbagai sudut pandang. Lebih lanjut, hasil evaluasi juga dapat digunakan oleh para pengambil kebijakan dalam memberikan program-program penguatan (misal: training) kepada guru.

\section{B. Guru Efektif dan Efektivitas Pembelajaran}

Beberapa jabaran tugas pokok dan fungsi guru di atas, dapat dijadikan dasar untuk mengatakan apakah seorang guru efektif atau tidak efektif, artinya dapat dilihat dari bagaimana seorang guru merencanakan pembelajaran, mengimplementasikan pembelajaran (KBM), dan mengevaluasi pembelajaran dengan berdasarkan standar mutu minimal. Lebih lanjut, seorang guru didalam melaksanakan tugasnya harus berdasarkan pada ilmu pengetahuan yang telah teruji kredibilitasnya atau efektivitasnya. Kemampuan guru dalam membaca setiap aspek pembelajaran baik materi, metode, strategi, murid, maupun lingkungan pembelajaran dalam menopang ketercapaian tujuan pembelajaran merupakan faktor kunci efektivitas guru dan pembelajaran.

Guru efektif yang menghadirkan efektivitas pembelajaran dapat difahami sebagai sukses mengajar dalam mencapai belajar murid yang diharapkan guru. Oleh karena itu, guru efektif dilihat dari upayanya pada bagaimana membuat murid belajar, sehingga ia harus melakukan pengajaran (pembelajaran) efektif. Terdapat dua elemen penting yang mendukung pengajaran efektif, yaitu:

a. Seorang guru harus memiliki kejelasan ide untuk apa pembelajaran dikembangkan.

b. Sebuah pengalaman belajar diatur dan disampaikan dan berusaha dicapai. 
Efektivitas pembelajaran (pengajaran efektif) menjadi variabel yang telah menarik peneliti pendidikan untuk mengkaji (meneliti) lebih jauh peran dan fungsinya dalam mendukung keberhasilan pendidikan. Pada tahun 1990an, penelitian tentang pengajaran efektif secara luas didominasi oleh usaha mengidentifikasi sifat-sifat guru (attributes of teachers) seperti; sifat personalitas (personality traits), jenis kelamin (sex), umur (age), pengetahunan dan pelatihan (knowledge and training), yangmana mendukung efektivitas mereka.

Chris Kyriacou dalam artikelnya yang berjudul "Effective Teaching in Schools: Theory and Practice" berpendapat bahwa berdasarkan berbagai penelitian yang ada guru efektif memiliki ciri-ciri sebagai berikut:

a. Kepribadian dan kemauan (personality and will)

b. Kecerdasan (intelligence)

c. Simpati dan Kebijaksanaan (sympathy and tact)

d. Berfikiran terbuka (open-mindedness)

e. Rasa humor (a sense of humour) (Kyriacou, 2009)

Selain pendapat di atas, untuk mencari definisi ideal tentang guru efektif perlu dipertimbangkan pendapat murid tentang gurunya. Dimana seorang murid melihat guru yang afektif di dasarkan pada; seorang guru adalah orang yang:

a. Menciptakan lingkungan belajar yang baik (creates a well-ordered learning environment)

b. Menjelaskan kerja yang kamu lakukan dan membantu kamu dengan itu (explains the work you have to do and helps you with it)

c. Merupakan sahabat dan pendukung (is friendly and supportive). (Kyriacou, 2009)

Secara berbeda dalam melihat pengajaran efektif, Perrot (dalam Dean, 2000: 51) lebih cenderung melihat efektivitas guru dalam pembelajarannya dari performance peserta didik (murid). Adapun indikatorindikator yang menunjukkan pengajaran efektif antara lain:

a. Murid menunjukkan pengetahuan dan pemahaman, kemampuan dan sikap yang diharapkan kurikulum sebagai ukuran kinerja pada test.

b. Murid menampilkan perilaku independen dalam mempelajari isi kurikulum.

c. Murid menunjukkan perilaku dengan indikasi sikap baik terhadap guru dan teman.

d. Murid menunjukkan perilaku dengan indikasi sikap baik terhadap kurikulum dan sekolah.

e. Murid menunjukkan perilaku dengan indikasi sikap baik terhadap dirinya sendiri sebagai pelajar.

f. Murid tidak menunjukkan perilaku bermasalah di kelas

g. Murid tampak aktif dalam belajar secara akademik sesuai materi ketika sesi kelas. (Dean, 2003)

Seorang guru efektif merupakan sosok yang melakukan pembelajaran secara efektif. Adapun karakteristik pembelajaran efektif adalah sebagai berikut:

a. Kejelasan dari penjelasan dan arahan guru

b. Membuat tugas-berorientasi iklim kelas

c. Membuat berguna berbagai aktifitas belajar

d. Membuat dan menjaga momentum dan langkah untuk pelajaran

e. Mendorong partisipasi anak dan membuat seluruh anak terlibat

f. Memonitor perkembangan anak dan mengikuti/memenuhi secara cepat kebutuhan anak

g. Menyampaikan pelajaran terstruktur dan terorganisir dengan baik

h. Memberikan anak balikan positif dan konstruktif

i. Menjamin cakupan dari tujuan pendidikan

j. Menggunakan teknik bertanya yang baik. (Kyriacou, 2009)

Lebih lanjut, untuk dapat menjadi guru efektif, seorang pengajar (pendidik) harus memiliki skill (keterampilan) kunci sebagai berikut:

a. Mencoba untuk menjamin pencarian kapabilitas dari seluruh anak (peserta didik).

b. Peduli pada suatu keputusan yang tidak dipengaruhi ekspektasi negatif terkait; kelas sosial, gender atau ras (suku).

c. Membangun kapabilitas yang telah dimiliki murid, tidak pernah memberi kesan apa yang mereka bawa (misalnya cara berbicara) tidak bernilai (valueless).

d. Mengingat bahwa perbedaan yang ada atau diperkuat di sekolah, menjelaskan hampir seluruh aspek dari sebuah masa depan anak, secara bersama-sama memainkan bagian besar di dalam menjelaskan struktur sosial masa depan. (Dean, 2003)

Dalam melakukan analisis terhadap efektivitas guru dalam pembelajaran maupun pengajarannya dapat juga menggunakan salah satu indikator yang dikembangkan oleh The Organisation for Economic Co-operation and Development (OECD, 1994) yang fokus pada ;

a. Pengetahuan dari subtansi isi kurikulum (Knowledge of substantive curriculum content). 
b. Kemampuan pedagogik termasuk kemampuan menggunakan sandiwara dari strategi mengajar (Pedagogic skills involved in the ability to use a repertoire of teaching strategies).

c. Refleksi pada pengajarannya sendiri dan kemampuan untuk mengkritik dirinya sendiri (Reflection on one's own teaching and the ability to be self-critical).

d. Empati dalam pernyataan memuji orang lain (Empathy in acknowledging the dignity of others).

e. Kemampuan manajerial di dalam maupun diluar kelas (Managerial competence within and outside the classroom). (Kyriacou, 2009)

Dari berbagai pandangan terkait guru efektif atau pengajaran efektif di atas, dapat disimpulkan bahwa untuk berhasil dalam pembelajarannya seorang guru harus mampu membawa dirinya pada efektivitas yang diharapkan. Guru efektif akan membawa pengajaran dan pembelajaran menjadi efektif, dan pada akhirnya akan membawa pada pencapaian tujuan pembelajaran secara efektif. Untuk menjadi efektif, seorang guru perlu memiliki karakteristik-karakteristik yang mendukung pada efektivitas pembelajaran.

\section{Urgensi Training dalam Pengembangan Profesinalitas Guru dan Mutu Pembelajaran (Efektivitas Pembelajaran)}

Guru bukanlah malaikat, guru merupakan manusia biasa yang mengemban tugas sebagai pendidik. Sebagai manusia biasa seorang guru tidak dapat lepas dari keterbatasan-keterbatasan manusiawi. Guru dengan keterbatasannya dituntut selalu profesional dalam menjalankan tugas profesionalnya. Sejalan dengan pendapat Christopher Day dan Judyth Sachs (2004:146) dalam bukunya yang berjudul International Handbook on the Continuing Professional Development of Teachers, ia berpandangan bahwa mengajar merupakan sebuah profesi tanpa akhir selamanya, sehingga pengembangan profesional (professional development) merupakan hal penting terhadap pekerjaan mengajar yang harus secara kontinyu dikembangkan dan ditingkatkan (Day \& Sachs, 2005).

Seorang guru memainkan bagian (peran) besar dalam pekerjaan professional dan keberhasilan peserta didik. Sehingga konsepsi dari keberlanjutan profesional dibutuhkan untuk dimasukkannya dalam pendidikan diri, termasuk emosi (Day \& Sachs, 2005). David Hargreaves (1994) mengidentifikasi sebuah model 'post-technocratic' dari pengembangan profesional;

a. Guru faham untuk memiliki kebutuhan belajar profesional sepanjang hayat;

b. Untuk keberlanjutan dan perkembangan agar terealisasi, hal itu harus dinilai secara rutin;

c. Rencana pengembangan sekolah harus memasukkan peluang pengembangan professional

d. Kebutuhan pengembangan personal harus direkonsiliasi dengan kebutuhan sekolah.

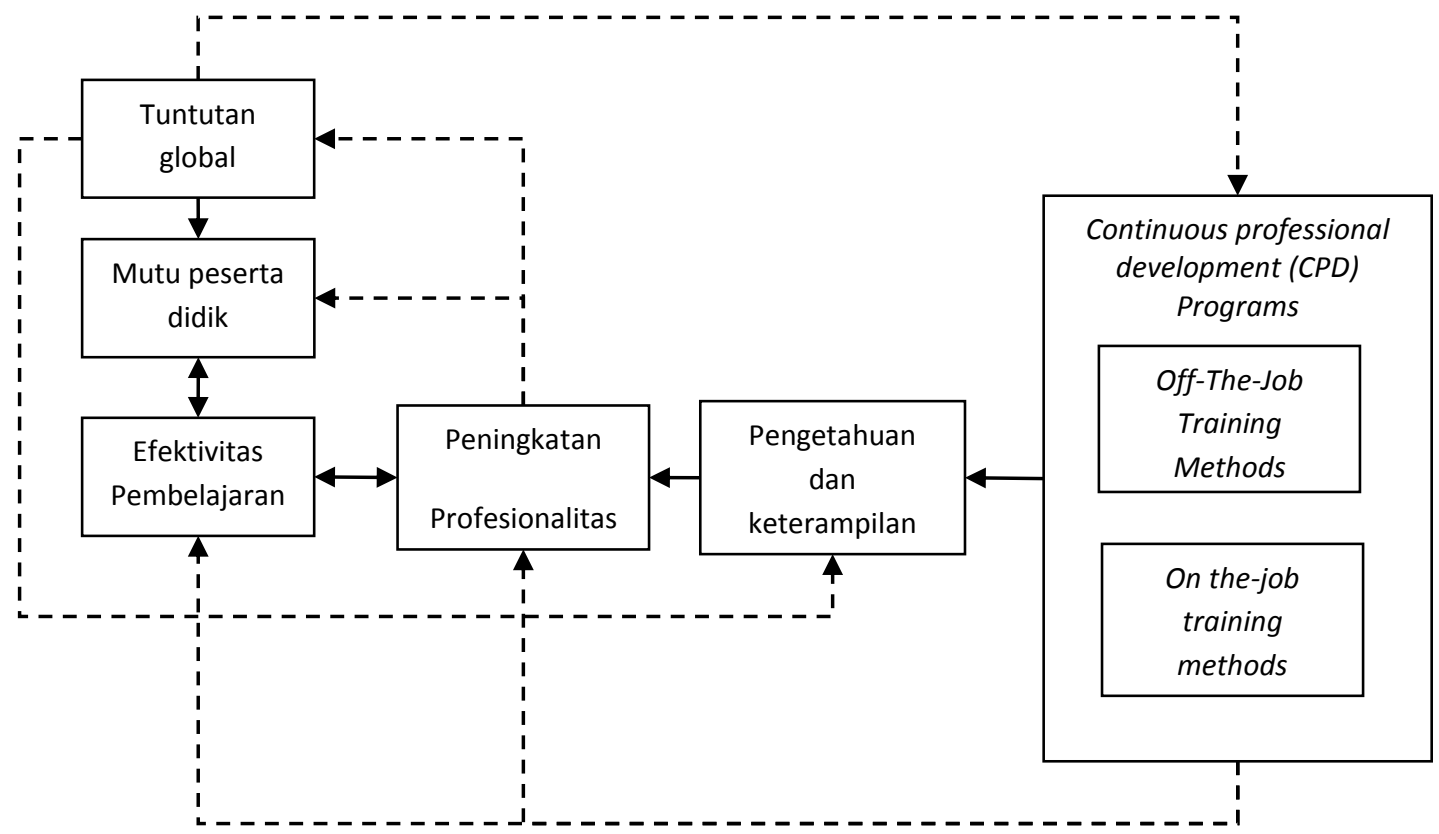

Gambar 1. Model rasionalitas kebutuhan training guru 
Pengembangan profesional disebut Christopher dan Judyth (2004:220) dalam tulisannya dengan istilah CPD (Continuous Professional Development). CPD merupakan sebuah proses menghasilkan interaksi penuh makna dengan konteks (ruang dan waktu) dan akhirnya membawa pada perubahan dalam praktik profesional guru (tindakan) dan dalam berfikir terkait praktik pembelajaran (Edens, Bell, Bennett Jr., \& Arthur Jr., 2003). Dalam dunia bisnis, kebutuhan berlanjut untuk pengembangan individu dan organisasi dapat ditemukan pada sejumlah tuntutan, termasuk menjaga superioritas dalam pasar, meningkatkan kemampuan pekerja dan pengetahuan serta meningkatkan produktivitas

Pengembangan profesional berkelanjutan dalam sebuah organisasi biasanya merupakan tugas dari departemen sumberdaya manusia. Dimana tugas tersebut untuk meningkatkan efektivitas organisasi dengan menyiapkan pekerja dengan pengetahuan (knowledge), kemampuan (skill) dan sikap (attitudes) yang akan meningkatkan kinerja pekerjaan mereka saat ini atau masa depan (Tuzun, 2005). Pengembangan organisasi terstruktur dapat dilakukan melalui pelatihan atau training terprogram. Pelatihan (training) diyakini sebagai suatu metode yang lebih meresap untuk meningkatkan produktivitas individu dan menyampaikan/mengkomunikasikan tujuan organisasi kepada personel baru (pegawai baru) (Edens et al., 2003). Training pada hakekatnya merupakan bagian dari pengembangan sumberdaya manusia, yang berhubungan dengan aktivitas sumberdaya manusia lainnya, seperti penerimaan (rekrutmen), seleksi dan kompensasi (Tuzun, 2005).

Training dibutuhkan dalam berbagai bentuk organisasi, baik bisnis maupun pendidikan. Training selain digunakan untuk mengenalkan pegawai baru atau guru baru pada tujuan organisasi (sekolah) juga dilakukan untuk pengembangan berkelanjutan sebagai jawaban dari dinamika lingkungan yang ada. Training dalam berbagai bentuknya dimanfaatkan untuk pengembangan professional berkelanjutan (continuous professional development) guru dalam mendukung kemampuannya (kompetensinya) dalam menghadirkan pembelajaran yang efektif.

\section{Model-model Training (pelatihan) untuk Peningkatan Pengetahuan dan Keterampilan Guru}

Secara bahasa kata training berasal dari kata kerja "to train" berasal dari bahasa Perancis trainer, maknanya "to drag" (untuk menarik). Dalam definisi bahasa inggris mungkin diketemukan berbagai makna seperti; to allure; to cause; to grow in the desired manner; to prepare for performance by instruction, practice exercise, etc. King (1968:125) berpendapat bahwa training dapat dijelaskan sebagai "providing the conditions in which people can learn effectively" (menyiapkan kondisi dengannya seseorang dapat belajar secara efektif) (Tuzun, 2005).

Menurut Flippo (1971) pelatihan (training) merupakan sebuah tindakan dari meningkatkan pengetahuan dan kemampuan dari sebuah pekerja untuk melakukan sebuah pekerjaan tertentu. Sejalan dengan itu, Beach (1980) berpendapat bahwa pelatihan merupakan prosedur yang terorganisasi dengannya orang-orang belajar pengetahun dan/atau kemampuan untuk tujuan tertentu (Punia, B K, 2013).

Pelatihan (training) merupakan sebuah "opportunity" untuk belajar dan hal itu disediakan untuk pekerja dengan peluang untuk belajar bagaimana bekerja lebih efektif dan dengan mempersiapkan mereka untuk setiap perubahan dalam pekerjaan mereka. Training (pelatihan) fokus pada acquisition of knowledge (kemahiran pengetahuan), kemampuan (skill), dan sikap (attitudes) yang dibutuhkan untuk bekerja lebih efektif pada pekerjaan baru (Tuzun, 2005). Peran dari training (pelatihan) mungkin tampak sebagai "menjamin bahwa organisasi memiliki orang-orang dengan pencampuran yang benar dari perlengkapan-perlengkapan yang ada, melalui penyediaan kesempatan belajar yang tepat dan memotivasi orang-orang untuk belajar, dan demikian memungkinkan mereka untuk berkinerja pada level tinggi dari kualitas dan layanan"(Tuzun, 2005).

Pelatihan efektif (Effective training) diyakini dapat meningkatkan pengetahuan (knowledge), kemampuan (skill), sikap (attitides) dan perilaku dari orang-orang dan meningkatkan kinerjanya". Program pelatihan efektif (effective training program) membantu organisasi mencapai tujuan mereka. Tujuan umum dari aktivitas training adalah; oriantasi pekerja baru terhadap organisasi dan pekerjaan mereka, membantu para pekerja berkinerja baik pada pekerjaan baru mereka, membantu pekerja memenuhi syarat (qualify) untuk pekerjaan masa depan, memelihara pekerja terinfokan perubahan dalam organisasi, menyediakan kesempatan untuk pengembangan personal (Tuzun, 2005).

Sejalan dengan beberapa pandangan di atas, pelatihan guru dilakukan untuk menjamin keberlangsungan profesinya. Artinya dalam pengajarannya seorang guru senantiasa menjaga efektivitas dan kualitas pelaksanaan pembelajaran berlandaskan ilmu pengetahuan dan perkembangan terbaru. Pelatihan atau training perlu mempertimbangkan kebutuhan guru dan kesesuaian pendekatan maupun metode training yang digunakan.

\section{Metode Training}

Metode pelatihan dapat diklasifikasikan atas pendekatan kognitif dan perilaku. Metode kognitif (cognitive methods) menyediakan informasi lisan maupun tertulis, mendemonstrasikan hubungan antar konsep, atau menyediakan aturan bagaimana melakukan sesuatu. Metode tipe ini dapat juga disebut dengan off the-job training methods. Disisi lain, behavioral methods (metode perilaku) memungkinkan trainee (peserta training) untuk mempraktekkan perilaku dalam kondisi nyata atau secara simulasi. Mereka menstimulasi belajar melalui perilaku yang terbaik untuk pengembangan keterampilan (skill) dan perubahan sikap, metode ini dapat disebut on-the-job training methods (Tuzun, 2005).

Woods (1995:180) berpendapat bahwa sebuah metode pelatihan harus memotivasi peserta pelatihan untuk meningkatkan kinerja mereka, mendemonstrasikan kamampuan yang diinginkan, menyediakan peluang untuk partisipasi aktif peserta, menyediakan kesempatan untuk praktek, menyediakan balikan segera pada kinerja peserta, menyediakan beberapa makna untuk penguatan saat peserta belajar, membuat bentuk 
terstruktur dari pelaksanaan kepada tugas kompleks, beradaptasi terhadap problem khusus, mendorong transfer positif dari training kepada pekerjaan (Tuzun, 2005). Secara garis besar metode pelatihan (training method) dijelaskan sebagi berikut:

1.1. Off-The-Job Training Methods

Metode off-the job training merupakan metode pelatihan mengambil tempat dalam lingkungan lain atau berbeda dengan tempat kerja. Metode ini selalu didesain untuk memenuhi kebutuhan belajar bersama dari sebuah kelompok dibanding kebutuhan individu tertentu. Kuliah, pelatihan berbasis komputer, permainan dan simulasi merupakan bentuk baru dari off-the job training (Tuzun, 2005). Adapun gambaran singkat dari metode baru tersebut adalah sebagai berikut:

a. Lecture Method

Metode Lecture cocok digunakan untuk menciptakan sebuah pemahaman umum dari sebuah topik atau untuk mempengaruhi sikap melalui pendidikan terkait sebuah topik. Konsen utama metode ini adalah tidak adanya kesempatan selama proses untuk mengklarifikasi tingkat pemahaman partisipan.

b. Computer Based Training (CBT)

Pelatihan berbasis komputer dapat didefinisikan sebagai setiap pelatihan (training) yang dilakukan dengan menggunakan computer. Beberapa alasan yang digunakan dalam penerapan metode ini adalah; mengurangi waktu belajar peserta, mengurangi biaya pelatihan, menyediakan petunjuk yang konsisten, memberikan privasi belajar, peserta dapat belajar hanya apa yang ia butuhkan untuk diketahui, meningkatkan akses terhadap pelatihan, memungkinkan peserta menjadi ahli pembelajar, cara terbaik untuk mendapatkan interes dan motivasi tinggi (Tuzun, 2005).

c. Games and Simulation

Model training games and simulations (pelatihan game dan simulasi) didesain untuk menghasilkan atau menstimulus proses, kejadian atau keadaan yang terjadi dalam pekerjaan peserta. Peserta dapat mengalami kejadian tersebut dalam sebuah wilayah setting terkontrol, dimana mereka dapat mengembangkan kemampuan mereka atau menemukan konsep-konsep yang akan meningkatkan kinerja mereka. Metode yang digunakan dalam games and simulasi yang sering diterapkan dalam dunia bisnis diantaranya;

1) Vestibule Training menyertakan duplikasi nyata dari lingkungan kerja dalam sebuah off-site setting.

2) Business Games merupakan bentuk lain dari simulasi yangmana peserta belajar bagaimana untuk sepakat dengan berbagai isu dalam sebuah lingkungan bisnis simulasi.

3) In Case Study method, merupakan detail dari rangkaian kejadian, baik nyata atau hipotesis, mengambil tempat dalam sebuah lingkungan bisnis.

4) In -Basket Exercises merupakan bentuk dari simulasi dengannya partisipan ditanya prioritas masalah, pesan, laporan, dan item lain yang mungkin ditemukan dalam manager's in-basket (Jerris, 1999:330)

5) Tujauan metode role playing adalah untuk memberikan partisipan sebuah kesempatan untuk pengalaman seperti stuasi dalam setting terkontrol (Tuzun, 2005).

Metode-metode di atas perlu dianalisa tingkat kesesuaiannya dengan kebutuhan peserta training. Berikut ini adalah gambaran terkait kesesuaian metode dengan kebutuhan maupun tujuan pelatihan;

1) Vestibule training obviously is best at teaching people how to work with equipment.

2) Business games are best for developing business decision-making skills and for exploring and solving complex problems

3) The in-basket technique is best suited to development of strategic knowledge used in making day-to-day decisions.

4) Case studies are most appropriate for developing analytic skills, and complex problem-solving strategies. Because trainees do not actually implement their decision or solution, its focus is more on the "what to do"(strategic knowledge) than on the "how to get it done"(skills)

5) Role plays provide a good vehicle for developing interpersonal skills and personal insight, allowing trainees to practice interacting with others and receiving feedback.

Berdasarkan catatan di atas, dapat ditarik kesimpulan bahwa tidak semua metode sesuai dengan semua maksud dan tujuan diadakan training. Kesesuaian antara metode dengan tujuan yang ingin dicapai melalui training menjadi pertimbangan bagi penyelenggara maupun organisasi. Kesesuian metode training dengan kebutuhan akan berdampak pada output dan outcome peserta. Metode-metode training di atas perlu mendapat sentuhan khusus sehingga dapat diterapkan (efektif) dalam memberikan pengalaman kepada guru guna mendukung pengembangan profesionalnya.

1.2. On-The-Job Training Methods

Tujuan dari metode on-the-job training adalah untuk membekali pekerja dengan pengetahuan kuhusus terkait tugas dan kemampuan dalam wilayah pekerjaannya. Pengetahuan dan kemampuan ditampilkan selama on-the-job secara langsung dihubungkan kepada kebutuhan pekerjaan. Job instruction technique, job rotation, coaching dan apprenticeship training merupakan bentuk-bentuk baru metode on-the-job training. Adapun deskripsi dari ketiga bentuk metode on the job adalah sebagai berikut:

a. Job Instruction Training adalah pendekatan terstruktur terhadap pelatihan, dengannya peserta dituntut berproses melalui seri dari tahapan dalam urutan yang ditetapkan. 
b. Job Rotation merupakan pergerakan sistematis dari pekerja dari pekerjaan ke pekerjaan, proyek ke proyek dalam organisasi, sebagai sebuah cara untuk mencapai berbagai perbedaan tujuan sumberdaya manusia, seperti; simply staffing jobs, orienting new employees, preventing job boredom or burnout, rewarding employees, enhancing career development, exposing employees to diverse environments (Woods, 1995:188).

c. Coaching adalah proses dari panduan dan instruksi one-on-one untuk meningkatkan pengetahuan, kemampuan dan unjuk kerja. Coaching sangat populer sebagai alat pengembangan, dan juga termasuk bekerja one-on-one dengan murid untuk mengadakan sebuah penilaian kebutuhan. Dengan membuat tujuan utama untuk dicapai, mengembangkan sebuah rencana tindakan, dan mendukung murid untuk menjalankan rencana.

d. Apprenticeship_ (magang) adalah satu dari bentuk lama pelatihan yang didesain untuk rencana penyediaan. Instruksi atau arahan praktik melalui sebuah durasi waktu yang signifikan. Apprenticeship menjadi pendekatan utama untuk learning a craft (belajar sebuah keahlian). Magang merupakan proses bekerja dengan seorang ahli magang yang diakui (a recognized mastercraft person) (Tuzun, 2005).

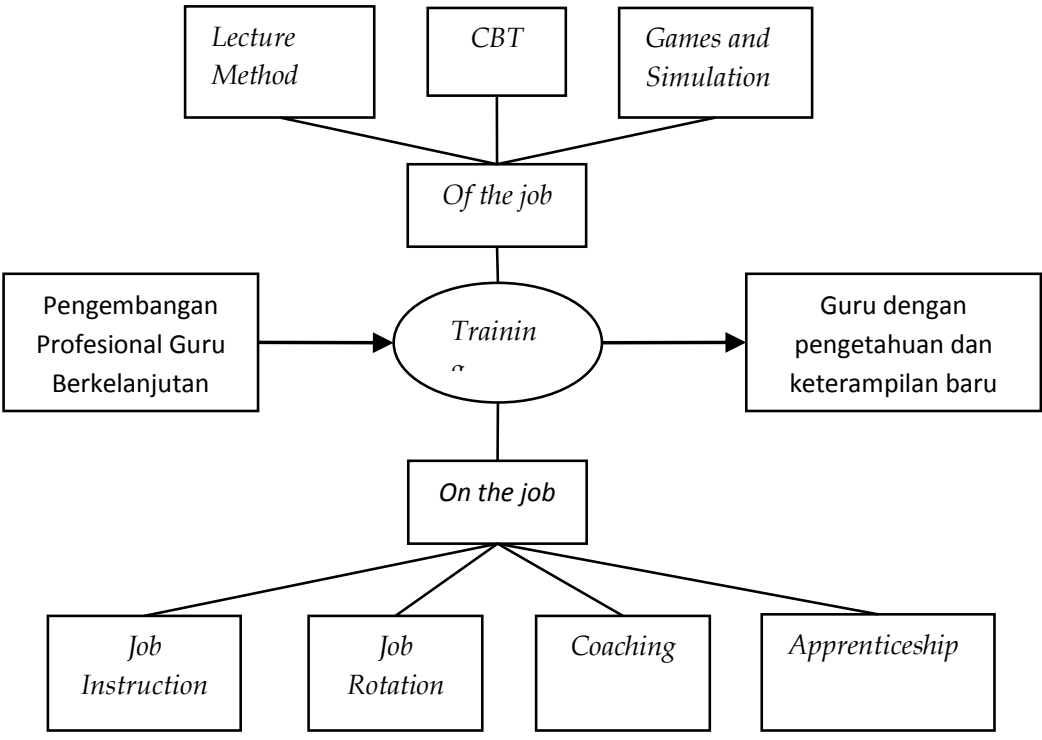

Gambar 2. Model Training dalam Pengembangan Profesional Guru Berkelanjutan (Continuous Professional Development)

Gambar 2 di atas menunjukkan bahwa pengembangan professional guru berkelanjutan dapat dilakukan melalui pelatihan atau training (on/of the job) yang berorientasi pada peningkatan pemahaman (pengetahuan) dan keterampilan baru atau yang lebih baik dari guru. Pengetahuan dimaksud dapat berupa pengetahuan dalam bidang regulasi, bidang ilmu, metodologi dan lain-lain. Oleh karenanya, pelatihan menempati posisi penting di dalam sebuah lingkungan dimana pekerjaan kompleks dan berubah seperti guru yang bekerja berkaitan dengan siswa dan ilmu pengetahuan. Keberhasilan pelatihan pengembangan professional dapat mencapai tujuannya apabila pelatihan senantiasa dijaga dan ditingkatkan efektivitasnya.

\section{Evaluasi Program Training}

Penyelenggaraan pelatihan membutuhkan evaluasi dan pengembangan guna mencapai efektivitas yang tinggi. Evaluasi efektivitas pelatihan senantiasa dijelaskan dengan menilai beberapa kombinasi dari kriteria yang ada, misalnya dalam Kirkpatrick's (1967) hierarchical model of training outcomes, evaluasi disusun dari empat tingkatan output training; (a) reaksi peserta training terhadap isi program dan proses pelatihan (reaction), (b) pengetahuan atau kemampuan yang didapat (learning), (c) perubahan perilaku (behavior), dan (d) perkembangan nyata individu atau keluaran organisasi seperti turn-over, accidents, atau productivity (result) (Punia, B K, 2013). Dari sudut pandang yang berbeda, Shepherd (1999) menjelaskan kriteria evaluasi untuk mengukur keberhasilan pelatihan meliputi; biaya langsung, biaya tidak langsung, efisiensi, kinerja jadwal, reaksi, pembelajaran, perubahan perilaku, dan perubahan kinerja (Punia, B K, 2013).

Penilaian terhadap efektivitas hakekatnya untuk mengetahui pengaruh pelatihan dan pengembangan terhadap; peningkatan pengetahuan dan keyakinan, mengurangi kecemasan, serta membangun keterampilan, sikap dan perilaku(Punia, B K, 2013). Efektivitas pelatihan guru pada akhirnya berakhir pada kinerja dan 
produktivitas guru dalam pelaksanaan tugasnya. Guru dengan kinerja yang baik menghadirkan pembelajaran yang efektif di kelas untuk membawa peserta didik pada pencapaian maksimal.

\section{Kesimpulan}

Perkembangan dunia yang dinamis menuntut adanya respon yang baik dari setiap organisasi, termasuk organisasi pendidikan. Respon organisasi pendidikan terkait perkembangan ilmu pengetahuan dan teknologi serta lingkungan yang ada merupakan faktor kunci keberhasilan pendidikan. Perkembangan tersebut juga harus difahami guru, sebab guru merupakan ujung tombak pendidikan yang bersentuhan langsung dengan peserta didik.

Guru profesional senantiasa cepat merespon perkembangan di sekitarnya. Namun guru tetap manusia biasa yang memiliki keterbatasan-keterbatasan. Sehingga pelatihan dibutuhkan untuk menutupi keterbatasan yang dimiliki guru dalam berbagai hal terkait pembelajaran. Pelatihan dapat didesain dalam dua bentuk baik off-the-Job Training maupun on-the-job training. Kedua metode tersebut dapat disesuaikan dengan kebutuhan guru dalam hal pengembangan pengetahuan, kemampuan dan sikap dalam melaksanakan profesinya. Dengan pelatihan efektif guruguru dapat tumbuh dan berkembang sesuai dengan perkembangan dunia yang dinamis. Sehingga pencapaian tujuan pendidikan secara tidak langsung dapat efektif sesuai dengan tarjet yang ditetapkan.

\section{Reference}

Day, C., \& Sachs, J. (2005). International handbook on the continuing professional development of teachers. McGraw-Hill Education (UK)

Dean, M. J. (2003). Improving children's learning: Effective teaching in the primary school. Routledge.

Djamarah, Syaiful Bahri, A. Z. (1998). Strategi Belajar Mengajar Modul. Jakarta: Rineka Cipta.

Djuwarijah, D. (2008). Peningkatan Kualitas Sumber Daya Manusia Melalui Pendidikan Islam. El-Tarbawi, 1(1), 1326. https://doi.org/10.20885/tarbawi.vol1.iss1.art2

Edens, P. S., Bell, S. T., Bennett Jr., W., \& Arthur Jr., W. (2003). Effectiveness of training in organizations: A metaanalysis of design and evaluation features. Journal of Applied Psychology, 88(2), 234-245. Retrieved from http://www.apa.org

Hamalik, O. (2007). Dasar-dasar pengembangan kurikulum. Bandung: PT. Remaja Rosdakarya.

Kemendikbud. (2014). Renstra Kemendikbud 2010-2014 [Perguruan Tinggi]. Retrieved from https://kemdikbud.go.id/dokumen/renstra-2010-2014/Bab-III.pdf

Kemenkeu. (2017). Perekonomian Indonesia dan APBN 2017 [Kementerian Negara]. Retrieved from https://www.kemenkeu.go.id/apbn2017

Kyriacou, C. (2009). Effective Teaching in Schools Theory and Practice (Third Edit). United Kingdom: Stanley Thornes.

Muhaimin, M. A., \& Ali, N. (2004). Paradigma Pendidikan Islam. Bandung: Remaja Rosda Karya.

Ngalim, P. (2011). Evaluasi Hasil Belajar. Yogyakarta: Pustaka Pelajar.

Ngalim Purwanto. (2009). Prinsip-prinsip dan Teknik Evaluasi Pengajaran. PT Remaja Rosdakarya. Bandung: Remaja Rosdakarya.

Punia, B K, S. K. (2013). a Review of Factors Affecting Training Effectiveness Vis-À-Vis Managerial Implications and Future Research Directions. International Journal of Advanced Research in Management and Social Sciences, 2(1), 151164.

suparlan. (2008). menjadi guru efektif. In menjadi guru efektif (p. 12). Yogyakarta: Hikayat Publishing.

Tuzun, I. K. (2005). General Overwiew of Training Effectiveness and Measurement. Journal of Commerce \& Tourism Education Faculty, 1(1), 144-156. 